\title{
BUILDING COMMUNICATION BETWEEN FAMILY MEMBERS AS A FORT OF FAMILY RESILIENCE
}

\author{
Jeri Ariansyah ${ }^{1}$
}

\begin{abstract}
This paper discusses about building communication between family members as a fortress of family resilience. The family is the basis for maintaining diversity, the family is very important to maintain the social understanding of family. As social beings, humans are never separated from communication. Communication is often a fundamental problem in one's family household relations, especially what often becomes a conflict is communication between husband and wife who lacks understanding of the concept of communication patterns in the family in order to maintain family resilience in the household. The purpose of this paper is to provide and express the concepts and principles of communication in the family so that it can be a solution on how to build communication in the family that can fortify family resilience. As for the focus in this paper is how the concept of communication patterns, communication as an ethical value to realize family resilience, communication as the realization of ma'ruf relationships in the family, the theory of ethical values and their relevance to the family communication system and the concept of family resilience. This paper is included in the type of normative legal research literature (library research). By using a conceptual approach and a statutory approach. the type of data in this study using qualitative data. The results of this paper conclude that family resilience is very influential on the concept of communication in the family. By understanding the concepts and principles of communication patterns between family members, they can maintain resilience and strength in the family, so that they can realize the purpose of marriage, namely forming a sakinah, mawaddah and rahmah family as contained in the Qur'an Surah Ar-Rum verse 21.
\end{abstract}

Keywords: communication, family resilience, social

\section{The Introduction}

The family is the pillar of national development as well as the first and foremost environment that has an important role in meeting the needs of 'honing, loving, and nurturing', as well as the foundation for developing and channeling the potential of each family member. Family in Islam is a household that is built from a marriage between a man and a woman which is carried out according to Islamic religious law that meets the requirements of marriage and the existing pillars of marriage.

In the view of Islam, the family has a very large value. Even in Islam, it pays great attention to family life by laying down wise rules to protect family life from disharmony and destruction. Why is Islam so concerned with the family? Of course, it cannot be denied that the family is the main foundation for building the palace of the Muslim community and is a madrasa of faith which is expected to produce generations of Muslims who are able to

1 Universitas Islam Negeri Sunan Kalijaga Yogyakarta, Email. jeriariansyah8@gmail.com 
exalt the religion of Allah on earth. If the religious foundation of the family is strong, the religion and morals of its members are straight, then the community will also be strong and the desired security will also be realized. On the other hand, if family ties are torn apart and damage poisons its members, the negative impact will be seen on society.

Families must be able to carry out their functions properly in order to be able to provide stronger resilience. When the family is able to harmonize and carry out its functions properly, automatically social resilience will be formed. Because in the family there is a process of learning life through the role of running functions. These are all real experiences for each family member to survive.

Household problems can be overcome if communication problems can be handled properly (Kathleen, Kuntara, and Jonathan, 2003: 9). Disharmony and destruction in the household or family can occur due to internal and external factors in the family. Internal factors in the form of time intensity, the less communicating face-to-face this is something that the informants complain about. Because in this digital era, family members are used to using their gadgets and social media. While external factors, in this case is the environment that affects habits in the family. The influence of the environment can also interfere with resilience in a family. Without realizing it, the environment can affect existing old habits to change, it can be positive or negative.

The relationship between family members is the relationship between husband and wife and children who must always live together under one roof has undergone a shift for some small communities in the modern era. As is the case now, the practice of modern society's household life, husband and wife carry out their respective official duties, while school children go all day or go to school outside the city which requires them to live in a dormitory, or boarding house, which then results in house buildings being only used to gather thoroughly between people. family members once a month. With such circumstances, it is necessary to have sufficient communication between family members, because basically everyone wants a family that is peaceful, peaceful, harmonious and sakinah.

To realize such a family life requires an ability that is not easy, it cannot even be disturbed by temptation, wherever it comes from. It can only be achieved by families who have resilience. People yearn for a family that can withstand riches, endure poverty, withstand praise, and withstand criticism (Ahmad Tafsir, 1993:134). Family problems with long-distance relationships require strong resilience for family members, because external influences from the family structure will be greater, so family resilience is needed for households to realize a sakinah, mawaddah, warahmah household. Provision of scheduled direct communication and interaction is a procedure to realize the affection between family members through communication procedures using Islamic ethical values in the family, namely communicating in a way that is ma'ruf and harmonious physically and mentally.

In this paper, the author tries to develop by including the writings that have been studied and made by previous researchers related to this discussion. The following are previous studies, the journal written by M. Nur Kholis Al Amin, with the title Communication as an Effort to Build Family Resilience in the Study of "Theory of Ethical Values". The journal concludes 
that the principles of Islamic communication are then an effort to build family resilience, including through: politeness and low tone in communication, management in communicating for partners, and using sensitivity to feelings for partners.

Second, the journal written by Ditha Prasanti and Putri Limilia, entitled Positive Communication as an Effort to Maintain Family Resilience, concludes that the factors that cause family resilience to be disrupted are the difficulty of communicating directly and accustomed to using the media; positive communication as an effort to maintain the resilience of urban families in the current digital era.

As the research above made by previous researchers, there are differences in the discussion that the author discusses. Previous researchers discussed communication as an effort to build family resilience in the study of ethical value theory and positive communication as an effort to maintain family resilience. While in this writing, the author will discuss on a more general scope by combining the concept of communication patterns in the family with the values contained in Islamic perspective communication and developing a theory of ethical values in communication, namely, Building Communication Between Family Members as a Fortress of Family Resilience. Therefore, in household conflicts caused by communication problems between family members often occur. So the importance of understanding the concept of communication that is built in the family, as well as providing solutions on how to communicate ideally in the family so that communication can become a stronghold of family resilience.

The systematic discussion of this paper is, the concept of communication patterns, Communication as an Ethical Value to Realize Family Resilience, Communication as the Realization of Ma'ruf Relationships in the Family, Theory of Ethical Values and Its Relevance to Family Communication Systems, the Concept of Family Resilience, and will be closed with conclusions.

\section{Research Methods}

This paper uses the type of research (library research). This research uses a conceptual approach and a statutory approach. the type of data in this study using qualitative data. Sources of research data using secondary data, namely data obtained from the Qur'an, books, journals, articles, laws and regulations and other writings related to family communication and family resilience. The form of the research is descriptive, which is collected from sources and analyzed in depth so that it can produce targeted conclusions.

\section{Discussion and Results}

\section{Communication Pattern Concept}

In a family relationship, communication is needed to control emotions, express anger, provide information, and even provide self-motivation to other family members. The inflexibility of the husband's or wife's parents plays its role both before the social and physical distancing period and after social and physical distancing shows that there is an undeveloped intimacy. This lack of understanding of the portion, role, and needs of family members is also what causes the stability of the duration of time with family is not optimal. So that many families experience communication functions and the context of family 
communication instead of interpersonal communication (Robeet Thadi, Adisel, Depi Putri, 2021:40).

Communication is a process of delivering messages, ideas, ideas from one party to another. Where there is a party acting as a source, and from that source will deliver a message to the recipient. The application of family communication as a form of interaction between parents and children as well as between family members has implications for the communication process, each family member will learn to know himself and understand his own feelings and the feelings of others. The communication process in the family always depends on the context of space and time.

A family has its own communication pattern that can minimize the occurrence of misunderstandings that can lead to misunderstandings. There are four (4) patterns of family communication that are common in nuclear families, namely: first, the pattern of communication equality (Equality Pattern), the pattern of communication of equality is a pattern of communication in the family by giving everyone the same rights in the decision-making process. So that the role of each person is carried out equally with communication running honestly, openly, directly, and free from the division of power. This pattern can also be referred to as the equality pattern. Second, a separate balanced communication pattern (Balance Split Pattern), this communication pattern in the family provides proportional or boundaries. Everyone in the family is seen as an expert in a different field. For example, in a normal/traditional family, the husband is trusted in business or political matters and the wife is trusted in child care and cooking. However, the division of roles based on gender is still flexible. Third, the pattern of unbalanced split communication (Unbalanced Split Pattern), this communication pattern positions one person in the family to dominate, one person is considered an expert over the others. One person is in control in the family who can make full decisions in the family. Fourth, the monopoly communication pattern (Monopoly Pattern), the monopoly communication pattern places one person as the holder of power that is giving orders rather than communicating. He has full rights to make decisions so he rarely or never asks or asks for opinions from others. So that other family members have to ask permission, ask for opinions, and make decisions based on the decisions of the family members who hold the power.

This difference in communication patterns illustrates the division of roles and positions of each individual in a family. Family communication patterns play a role in receiving messages and feedback that occur between family members. Thus the communication pattern equality (Equality Pattern) is a communication pattern that is very relevant in realizing family resilience. Because with the equality pattern (Equality Pattern), each member in the family can carry out their respective roles without any pressure and coercion from other family parties.

\section{Communication as an Ethical Value to Realize Family Resilience}

The family is a special structure in society that is formed from the household and is mutually binding. The family can also be referred to as the union of people who are bound by marriage, blood, or adoption. Marriage is a bond between husband and wife. Simply put, that the family in its simplest and most basic form consists of a man and a woman, living in a marriage 
bond, along with their children or minors who are recognized by the community (Kaelany HD, 2000:162).

Family problems with long-distance relationship patterns, although temporary, then strong resilience for family members is needed, because the external influence of the family structure will be greater. So that family resilience is needed for households to realize a sakinah, mawaddah, and rahmah. As for family resilience, it is defined by Ahmad Tafsir as a condition of a resilient family that can be expressed in various arrangements, including that the family is strong, resistant, or in other languages standing firm. In the government regulation of the Republic of Indonesia, Number 21 of 1994, defines family resilience as a dynamic condition of a family that has tenacity and toughness and contains physical-material and mental-spiritual abilities to live independently and develop themselves and their families to live harmoniously in improving birth welfare. and inner happiness (Ahmad Tafsir, 1993:134). Efforts to grow family resilience through communication procedures using Islamic ethical values in the family, namely communicating in a way that is ma'ruf and harmonious physically and mentally. How to communicate is very urgent for the continuity and resilience of the family.

\section{Communication as the Realization of Ma'ruf Relationships in the Family}

The problem of communication is one of the biggest problems in the world, therefore the problem of communication is a problem of human relations, has caused many bad consequences, to the existence of conflicts between countries, and even wars between tribes and races are caused by communication conflicts. Likewise in the household, many household problems can be solved properly through good communication as well (Kathleen Liwidjaja, Kuntara, M.D and Jonathan Kuntaraf, 2003:9). In realizing a sakinah, mawaddah, and rahmah family, it takes tenacity and toughness from each husband and wife to build a household, one of which is through a good communication relationship pattern.

The definition of communication in Webster's New Collegiate Dictionary as quoted by Abdul Chaer and Leonie Agustina: "Communication is a process by which information is exchange between individuals through a common system of symbols, signs, or behavior" (individual through a common system of symbols, signs, or behavior).

Marriage is a way to form a family household which in the study of fiqh munakahat husband and wife are couples who have bound a sacred agreement of different types and characters, so it is appropriate for each other to understand each other because basically in marriage there is an inherent social element. the husband-wife relationship is the purpose of marriage, the purpose of reproduction (biological), the goal of obtaining a peaceful life full of love, the purpose of honor, and the purpose of worship, which can be realized with the existence of mature family resilience. Communication is very important for relationships in the family, because without communication, close relationships cannot be established or survive, especially husband-wife relationships.

Allah SWT has said in the Qur'an which provides an explanation of the social relations of husband and wife, including: 


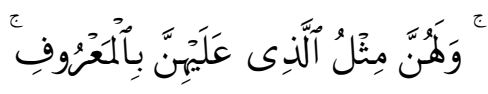

"And they women have rights that are balanced with their obligations according to the ma'ruf way."

Al-Qur'an Surah Al-Baqarah verse 228 shows that between husband and wife is a complementary relationship, an equal and partner relationship, so as partners must be able to relate well and harmoniously. In Surah AnNisa verse 19 explains that:

\section{"get along well with each other"}

In Surah An-Nisa verse 19, it is explained that in the relationship between husband and wife, it must be good, especially in matters of determining a living and a place to live. Thus, the two verses above can identify that the husband-wife relationship is very thick with social elements in accordance with the values that have been taught by religion, both in attitude and relationship (associating or relating) or in a broad scope called communication procedures.

In Qs Al-Baqarah 228 and Qs An-Nisa 19, it can be used as the main reference for husband-wife relationships to interact in a ma'ruf way so that they are able to realize their social needs in household buildings to create a sakinah family (calm), mawaddah (love) and rahmah. Therefore, communication is needed that is able to channel leniency between husband and wife family members so that there is no prejudice between the two.

Islam as a way of life teaches its people to become progressive people in various life systems, because in Islam there is at least a complete and perfect life system, including spiritual, moral, political, economic, and social systems (M. Amen, 2016:28). The moral and social system is a system that is very tied to one another, this system looks at the role of communication between family members. As Islam, through its teachings, has taught procedures for communicating between human beings, so that with this communication system the fulfillment of marital rights (for husband and wife) which aims to maintain the continuity and harmony of marriage can be realized.

The procedures for communicating in the family, especially for husband and wife, as the results of research by Kathlen Liwidjaja, Kuntara, MD and Jonathan Kuntaraf, which were then combined with Islamic communication values with the term politeness in communicating, namely: correct each other. Correcting your partner in public is one thing to avoid. Because basically correcting between partners in public is an unethical or impolite thing, especially correcting their own partners. Thus, when there are weaknesses between partners, they can be resolved personally first, which in the study of Islamic marriage law, is more likely to be introduced to the principle of deliberation to resolve problems in the family.

Second, avoiding the use of words that cause misunderstandings. Every couple does not necessarily consist of the same cultural background, so there are many cultural and linguistic differences. This needs to be anticipated and addressed wisely by the couple if both of them communicate with ethics that have been given standards in marriage law, such as having 
to provide an explanation through language that is understood by members of the couple. This is a form of realization that the husband and wife relationship is a partner relationship, that is, one must complement each other and be able to understand and understand.

Third, Participation Evaluation, participation evaluation is a form of ethics in establishing a harmonious relationship in one household building. By realizing that a typical partner is not the same, sometimes the husband is lower in tone than the wife, and vice versa, or sometimes the wife talks a lot, but the husband is more silent, so that each partner can ask each other for their partner's opinion to evaluate him, things like it is very important in the family.

Fourth, Be careful in interrupting the conversation, cutting or monopolizing the conversation often occurs in communication, both in formal and non-formal forums. Things like this should be avoided in the family, especially for husbands and wives when they are communicating seriously, cutting off the conversation is a form of disrespectful behavior in communication ethics, be it in Islamic ethics or civilized society ethics.

Fifth, Appreciating the time of arrival, in this section, will be focused on couples who are in long-distance relationships, so that when one partner comes to see the other is a very special time. This must be addressed by the partner by appreciating the couple's arrival. But also with couples who do not have long-distance relationships, when their partners come home from work, other couples must welcome his arrival properly. This is one of the polite and courteous ethics in Islamic marriage between husband and wife.

Sixth, Pay attention to the tone of voice, a person's habits can cause him to speak loudly without realizing that the loud volume has disturbed other people who are listening, so, every married couple must realize that shouting does not increase communication, but actually destroys communication. In fact, in Islamic values communication must be through a soft tone of voice, as stated in the Qur'an Surah Al-Hujurat verse 2:

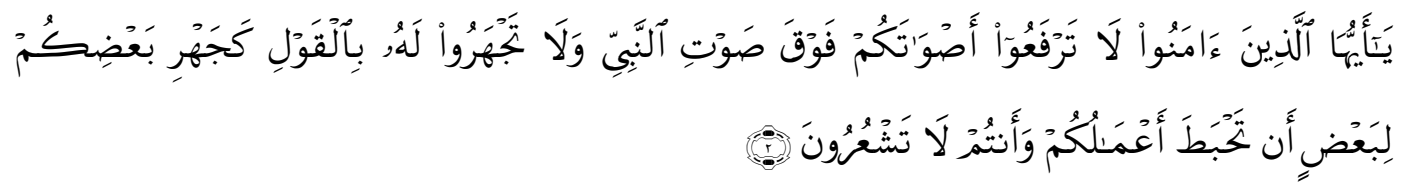

"O you who believe, do not raise your voice above the voice of the Prophet, and do not speak to him in a loud voice, as the voices of some of you are louder than others, so as not to erase (reward) your deeds, while you do not realize."

Seventh, Avoid painful jokes. Husband and wife must have sensitivity to avoid jokes that hurt their loved ones. Because basically excessive jokes will be able to create disharmony in the relationship between husband and wife.

\section{Theory of Ethical Values and Its Relevance to Family Communication Systems}

Humans are creatures in terms of physical (body) and spiritual (soul). The spiritual aspect of man consists of thoughts and feelings. When harmonized, it will produce a will which then becomes an attitude of action. That attitude then becomes the basis of human physical movement. The spiritual aspect of humans in the process of living with each other produces 
personality. The process of forming a person's personality is influenced by several factors, both from himself and from the environment (Soerjono Soekanto, 1998:127).

Since being imaged as social beings, humans cannot live outside the network of order, how and in whatever form. Sociality asserts that humans are group creatures, such as ants, bees and others (Satjipto Rahardjo, 2008: 7). In social life, humans are made into tribes and nations, so that they can be seen as social beings (Cik Hasan Basri, 2004: 8). One of the characteristics of social beings is to communicate to meet their spiritual needs, this also applies to family members in domestic life.

As suggested in Q.s An-Nisa verse 19, which is widely given meaning by Prof. Khoiruddin by using a normative-universal text approach that all Muslims and Muslim women wherever they live, at any time, nationality and from any ethnicity and race, are ordered to have good relations with their partners; the husband must get along well with his wife, as well as the wife must get along well with her husband (Khoiruddin Nasution, 2007:112). Islamic law is a study that has an integration between the fields of law (text, jurisprudence, figh) and social (context).

Role theory can be an ethical value in the family communication system. With the role theory, each party in the family is able to position themselves as a role in the family well. Role theory is a theory which is a combination of various theories, orientations, and disciplines. Apart from psychologists, role theory originated from and is still used in sociology and anthropology. In the three fields of science, the term "role" is taken from the world of theater. In theater, an actor must reflect as a certain character and in his position as a character he is expected to behave in a certain way. (Sarwono, 2013:215).

Roles or roles according to Bruce J. Cohen, also have several types, namely (S Fahrizal, 2019): The real role (Anacted Role) is a way that is actually carried out by a person or group of people in carrying out a role. Prescribed roles are the ways that society expects us to carry out certain roles. Role conflict is a condition experienced by someone who occupies a status or more that demands conflicting role expectations and goals. The role gap (Role Distance) is the implementation of the role emotionally. Role failure is a person's failure to carry out a certain role. A role model is someone whose behavior we imitate, imitate, and follow. The series or scope of roles (Role Set) is a person's relationship with other individuals when he is carrying out his role.

As for the role of each family member, including; The role of the father as the head of the family, who has the duty to protect his family from disturbance or harm. The father as the head of the family is also in charge of earning a living to meet the needs of his family and is responsible for the education of his children. The role of the mother as the second head of the family from the father is responsible for his family, especially his children. The task of a mother is not easy because she has to take care of and care for her family. Mothers are also responsible for raising children, providing food for the family, cleaning the house, managing family finances and paying attention to their children's education. Children as family members have a role to learn and respect their parents, make both parents proud, and help 
both parents as much and as much as they can. Children also have the right to protection and education from their parents.

Such as an assessment of the role of communication in the modern family which can be understood by using the method of ethical values to understand the texts in a nomative-universal manner, namely by understanding the texts that were revealed 14 centuries ago when the Prophet Muhammad was still alive, in relation to the practices and operations of the times and the present conditions are in many ways different from the times and conditions at the time of the Prophet, so a way of understanding these universal-normative texts is needed by stipulating the law of special cases faced today in line with the general principles that have been set forth in the texts (Khoiruddin Nasution, 2007:119)

The pattern of communication and relations between husbands today by referring to Article 32 of the Marriage Law and understanding it textually, will give birth to an understanding that communication must be carried out in one place of residence, where the husband is obliged to provide a place to live for the household. To regulate interaction for family members with several procedures as an effort to realize family resilience, which include: First, courtesy and low tone in communication. Islam has taught how a child should behave towards both parents, as stated in Q.s Al-Isra verses 23-24:

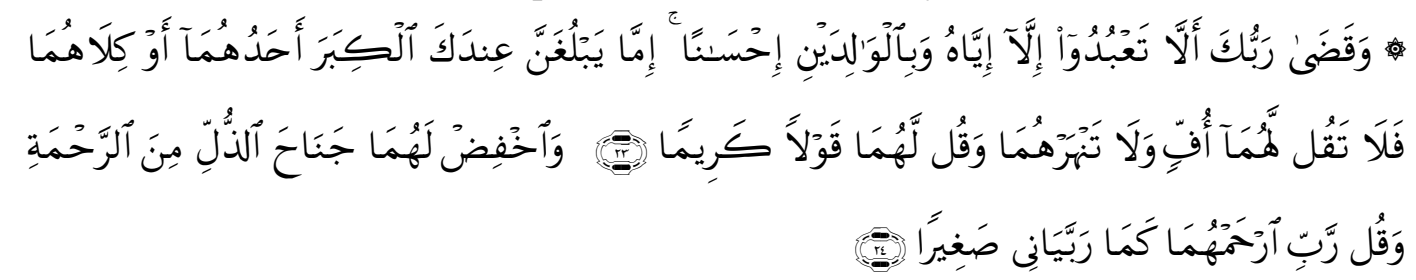

"And your Lord has commanded that you do not worship other than Him and do good to your parents as well as possible. if one of them or both of them reach old age in your care, then do not say to them the word "ah" and do not yell at them and say to them the word of honor. and humble yourselves towards them both with love and say: "O my Lord, have mercy on them both, as they both taught me when I was little".

The verse above, in addition to showing the procedures for communicating for children to their parents which can contain a prohibition against speaking harshly or yelling at parents, can also be implemented in the pattern of husband-wife relations so that between them communicate in a low tone and full of ways. the manners.

Second, management in communication, Islam or din Islam is a system in which aspects that regulate humans are collected, both human relationships with God (vertical), relationships between humans, and human relationships with nature or other living creatures (M. Nur Kholis Al-Amin, 2017:14). So that indirectly humans need time management and wisdom in interacting. By mastering the knowledge of family management, family resilience can be realized because each individual is able to understand their respective roles. The importance of understanding the role of individuals in family management communication patterns has been implicitly taught in the hadith narrated by Imam Bukhari: Meaning: every individual is a leader and every leader will be held accountable. The leader will be held accountable by the people he leads, the husband of the leader in his family will be held 
accountable from the one he leads, the woman (wife) is the leader of household affairs (her husband) and will be held accountable for her responsibility, and the servant is the leader of the master's property which he manages later. will also be held accountable. And every leader will be held accountable for what he leads. (Narrated by Bukhari).

Third, it is not easy to be emotional (emotional) in communicating. As social beings, humans cannot be separated from interaction and communication. Islam has set the procedures for communicating, one of which is not being emotional when communicating. Especially when communicating with a partner. Because these emotions can lead to depression and wrong decision making. Thus, Islam strictly forbids making decisions when emotional for the creation of family resilience and the realization of a sakinah, mawaddah, and rahmah family.

Fourth, using sensitivity to feelings towards partners, humans are born equipped with creativity, taste and intention, with their wealth they are able to give charity, with good morals they are able to pacify life in togetherness, with knowledge they are able to share and with sensitive feelings they are able to make their life partners happy. So, in addition to being knowledgeable, family members must have a Pangerten attitude and be responsive (understanding and responsive) to their respective partners in order to create a harmonious relationship and build family resilience and the realization of a sakinah, mawaddah, and rahmah family.

A basic element in law is that the law is something that relates to humans (C.S.T Kansil, 1989: 481). Islam introduces several intermediary rules to realize a harmonious marriage, which if these rules are truly maintained, then the life of husband and wife will be strong and eternal, and avoid destruction. Among these rules are: Recognizing the (noble) morals of the prospective husband and wife, Knowing the situation (understanding the character and physical) of husband and wife, Having pleasure between both parties (husband and wife), The existence of the concept of dowry for the wife, Cultivating a sense of love and affection for the husband and wife relationship so that a peaceful household life can be realized, as in Qs ArRum verse 21. Thus, if some of the rules as intermediaries above can be applied through good communication, especially in the attitude of cultivating a sense of love and affection, then family resilience can be realized.

\section{Family Resilience Concept}

Family resilience is the ability of the family to use the resources owned by the family in achieving family independence and welfare. A good and optimal pattern of family resilience makes the family more prepared and stronger in solving problems and difficulties faced by the family (Mujahidatul Musfiroh et al, 2019:65-66).

Law Number 52 of 2009 concerning Population Development and Development of Prosperous Families explains that family resilience is a dynamic condition of a family that has tenacity and toughness and contains physical, material and mental spiritual abilities to live independently, develop themselves and their families to achieve a harmonious state in life. improve physical and spiritual well-being (Law Number 52 Year 2009). Signs of a well-functioning family resilience at least have the following signs: Attitude to serve as a sign of glory, Intimacy between husband and wife 
towards good marriage quality, Parents who teach and train their children with creative challenges, consistent training and develop skills, Husband and wife who become leaders with love, Children who obey and respect their parents. The secret of family resilience/strength lies in the spirit of altuarism between family members, namely trying to do something for others, doing and moving together, maintaining family relationships, creating a positive atmosphere, protecting shared dignity and celebrating life together (Chapman, 2000).

There are two orientations, namely, conversation orientation and conformity orientation to values. These are variable, so families differ in how many conversations and according to the scheme the family includes. Families that have high conversations spend a lot of time talking about life in depth, on the contrary, families with low conversation schemes don't spend much time talking. Families with high conformity will be very obedient to the rules, while families with low conformity are more likely to have no rules in them, in other words being freed by the family. Our family communication patterns will depend on where our schemes fit in the two types of orientation (Erwinda Valdy Prakasa, Rezi Maulana, 2021:3).

How to build an ideal family is to plan the ideal age of marriage (Female $=21$ years $\&$ Male $=25$ years $)$, Build relationships with spouses, other families, and social groups, Plan the number of children, exclusively breastfeed babies for six months and continue to breastfeed until two years, Set the birth interval of children 3-5 years with contraception, Stop giving birth at the age of 35 years so that they can take care of them optimally, and Treat and care for children under five optimally (Isnu Harjo Prayitno, Edi Sofwan, Ibrohim, 81). With the establishment of an ideal family, it can also become resilience in the family. Because the ideal family, of course, has a strong family resilience, because the role in the family is carried out properly so that the functions in the family can function properly.

Family resilience can only be created if each family can carry out the eight family functions in a harmonious, harmonious and balanced manner. The intended family functions include: Religious function, parents are role models for their children in worship including daily attitudes and behavior in accordance with religious norms. Socio-cultural function, parents are examples of socio-cultural behavior by speaking, acting and acting in accordance with eastern culture so that children can preserve and develop culture with pride. The function of love, parents have the obligation to give love to children, other family members so that the family becomes the main place for the blossoming of a loving life. The function of protection, parents always try to foster a sense of security, comfort and warmth for all family members so that children feel comfortable at home. Reproductive function, parents agree to regulate the number of children and birth spacing and take care of their children, especially those who are teenagers, maintain healthy reproductive health, avoid pregnancy before marriage. The function of socialization and education, parents are able to encourage their children to socialize with their environment and receive education for their future. Economic function, parents are responsible for meeting the needs of their family. In the function of environmental development, parents always teach children to protect and maintain the environment, family harmony and the 
surrounding environment (Sofinas Z. Assari, Masayu S.Hanim, Elly Irawan, 2016: 10-11).

The family is mandated by Law Number 52 of 2009 concerning Population Development and Family Development: Chapter II: Part Three Article 4 paragraph (2), that family development aims to improve the quality of the family so that a sense of security, peace and hope for a better future can arise. both in realizing physical and spiritual well-being. A quality family is a family that is formed based on a legal marriage and is characterized by being prosperous, healthy, advanced, independent, has the ideal number of children, is forward-looking, responsible, harmonious, and fearful of God Almighty. Family quality is a family condition that includes aspects of education, health, economy, socio-culture, family independence and mental spirituality as well as religious values which are the basis for achieving a prosperous family. Family resilience and welfare is a family condition that has tenacity and toughness and contains material physical abilities to live independently and develop themselves and their families to live harmoniously in improving physical and spiritual well-being and happiness. Family empowerment is an effort to improve the quality of the family, both as a target and as a development actor, so as to create an increase in physical and non-physical resilience, independence and family welfare in order to realize quality human resources.

\section{Conclusion}

Based on the presentation of the material above, it can be concluded that, the principles of Islamic communication which are then applied as an effort to build family resilience, namely: Courtesy and tone in communication, Management in communicating, Not easily emotional (emotional) when communicating, Using sensitivity feelings for the partner.

Communication can be a stronghold in family resilience if family members can understand the concept of communication. Principles and patterns of communication affect the implementation of the role of each family member. So the selection of concepts, patterns, and principles of communication in the family greatly affects the realization of family resilience. So that family members can carry out the functions of the family.

Thus, the family structure at this time where there is still a decrease in the intensity of the interaction pattern among family members in the household, thus making communication into a conflict in the family caused by the times. So with the concepts and principles of communication patterns that have been briefly explained above, it is important to build communication patterns in the family so that they can maintain resilience and strength in the family, so that they can realize the goal of marriage, namely forming a sakinah.mawaddah and rahmah as contained in the Qur'an Surah Ar-Rum verse 21. 


\section{References}

Al-Qur'an Tajwid dan Terjemah. (2010). Bandung, cv Penerbit Diponegoro.

Al Amin, Nur M. Kholis. (2018). Komunikasi sebagai upaya untuk membangun ketahanan keluarga dalam kajian "teori nilai etik". Alahwal jurnal hukum keluarga Islam, 11(1), 79-90. https://doi.org/10.14421/ahwal.2018.11107

Al Amin, Nur M. Kholis. (2016). Intervensi Orang Tua dalam Rumah Tangga Anak;dalam Islam, Bolehkah. Solo, Azka Presindo.

Al Amin, Nur M. Kholis. (2017).Dahsyatnya Perjalanan Kehidupan Manusia. Solo: An-Naja.

Chapman. (2000). Gender dan Keluarga:Konsep dan Realita di Indonesia. Bogor, PT IPB Press.

Erwinda, Valdy Prakasa \& Maulana, Rezi. (2021). Hubungan Antara Komunikasi Orang Tua dengan Ketahanan Keluarga Remaja Disabilitas Rungu. e-Proceediing of Management, 8(4), 3915-3923.

Hasan Basri Cik. (2004) Pilar-pilar Penelitian Hukum Islam dan Pranata Sosial. Jakarta: PT. RajaGrafindo Persada.

H.D Kaelany. (2000) Islam dan Aspek-aspek Kemasyarakatan. Jakarta: Bumi Aksara.

Kansil C.S.T. (1989). Pengantar Ilmu Hukum dan Tata Hukum Indonesia. Jakarta: Balai Pustaka.

Liwidjaja Kathleen, Kuntara, M.D dan Kuntaraf Jonathan. (2003) Komunikasi Keluarga: Kunci Kebahagiaan Anda, cet.ke-3 (Bandung, Indonesia Publishing House.

Musfiroh, Mujahidul., Mulyani, Sri., Cahyanto, Erindra Budi., Nugraheni, Angesti \& Sumiyarsi, Ika. (2019). Analisis Faktor-faktor Ketahanan Keluarga Di Kampung KB RW 18 Kelurahan Kadipiro Kota Surakarta. Placentum, Jurnal Ilmiah Kesehatan dan Aplikasinya, 7(2), 61-66. https://doi.org/10.20961/placentum.v7i2.32224

Nasution Khoiruddin. (2007) Pengantar dan Pemikiran Hukum Keluarga (Perdata) Islam Indonesia, (Yogyakarta:Tazzafa \& ACAdeMIA).

Rahman Fazlur. (1976). Islamic Methodology in History. Islamabad: Islamic Research Institute.

Rahman Fazlur, Islam. (2000). Penerjemah; Ahsin Mohammad. Bandung: Pustaka.

Rahardjo Satjipto. (2008). Biarkan Hukum Mengalir, Catatan Kritis tentang Pergulatan Manusia dan Hukum. Jakarta: Kompas.

Soekanto Soerjono. (1998). Sosiologi Suatu Pengantar. Jakarta: PT RajaGrafindo Persada.

Sofinas Z. Assari, Masayu S.Hanim \& Elly Irawan. (2016). Telaahan Kebijakan (Pengaruh) Interaksi Komunikasi Efektif Antar Orang Tua dan Anggota Keluarga Terhadap Ketahanan Keluarga di Provinsi DKI Jakarta. Kementerian Pemberdayaan Perempuan dan Perlindungan anak dan Yayasan Melati.

Tafsir Ahmad. (1993) "Zikir dan Ketahanan Rumah Tangga", dalam Keluarga Muslim dalam Masyarakat Modern, Penyunting: Jalaluddin Rakhmat dan Muchtar Gandaatmaja. Bandung: PT Remaja Rosdakarya. 
Thadi, Robeet., Adisel, \& Putri, Depi. (2021). Peran dan Fungsi Komunikasi Keluarga dalam Aadaptasi Pranata Keluarga Islami di Tengah Pandemi Covid-19. Jurnal Ilmiah Syiar, 21(1), 33-44. http://dx.doi.org/10.29300/syr.v21i1.4237

Undang-undang Nomor 52 Tahun 2009 Tentang Perkembangan Kependudukan dan Pembangunan Keluarga Sejahtera. 